Bangladesh J. Pl. Breed. Genet., 26(2): 01-08, 2013

\title{
GENETIC DIVERSITY OF ASH GOURD (Benincasa hispida) GENOTYPES
}

\author{
M. M. R. Dewan, M. G. Rabbani ${ }^{2}$, U. A. Naher ${ }^{3}$, S. Pramanik ${ }^{1}$ and M. K. Quais ${ }^{1}$ \\ Rice Farming Systems \\ Bangladesh Rice Research Institute \\ Gazipur 1701, Bangladesh
}

\begin{abstract}
An experiment was conducted to study the field performance, variability and genetic divergence for yield and yield contributing characters of 46 ash gourd genotypes at the Horticulture Farm, Bangladesh Agricultural University, Mymensingh. Wide range of variations were found among the ash gourd genotypes in respect of different parameters such as vine length at harvest, fruit length, fruit diameter, sex ratio, number of fruits plant ${ }^{-1}$, average weight fruit $^{-1}$ and yield plant ${ }^{-1}$. The genotype $\mathrm{BH} 21$ showed the highest performance in number of fruits plant ${ }^{-1}$ and yield plant ${ }^{-1}$. In respect of average weight fruit ${ }^{-1}$, the genotype $\mathrm{BH} 16$ produced the heaviest $(1.86 \mathrm{~kg})$ fruit and the genotype BHl7 produced the lightest $(0.67 \mathrm{~kg})$ fruit. The genotype $\mathrm{BH} 18$ had the highest sex ratio (8.16) and the genotype $\mathrm{BH} 14$ had the lowest sex ratio (3.44). In case of number of fruits plant ${ }^{-1}$, the genotype $\mathrm{BH} 46$ and $\mathrm{BH} 53$ had the minimum number of fruits (1.33) and the genotype $\mathrm{BH} 21$ had the maximum number of fruits (16.16) per plant which was statistically similar with the genotype BH12 (15.00). The genotypes were also tested for genetic divergence utilizing the multivariate analysis. The genotypes were grouped into eight clusters. However, there was no relationship found between genetic divergence and geographic distribution of the genotypes.
\end{abstract}

Keywords: Fruit yield; vine length; flesh thickness; sex ratio

\section{INTRODUCTION}

Ash gourd (Benincasa hispida. Thumb.) belongs to the family cucurbitaceae. The cultivated species is B hispida, commonly known as ash gourd, tallow gourd, chinese water melon, white gourd, wax gourd (Tindall, 1986). In Bangladesh, ash gourd is popularly known as chall kumra. The history of ash gourd showed that, De Candolle (1986) found it wild in the sea shore of Java. It is also widely distributed throughout the tropical and subtropical Asia (Purseglove, 1987). However, Yawalkar (1985) mentioned that the original home of ash gourd is believed to be Java, where its wild progenitors are still found. Though it has been cultivated in China from the ancient period, it is not clearly known from what time this crop is being cultivated in the Indian subcontinent. It is widely cultivated in India, China, Malaysia, Indonesia, Philippines, Taiwan, Bangladesh and the Caribbean Islands (Tindall, 1986). In Bangladesh, green immature fruits and young twigs of ash gourd are used as vegetable. Matured fruits are used for the

\footnotetext{
${ }^{1}$ Rice Farming Systems, Bangladesh Rice Research Institute, Gazipur 1701, Bangladesh.

2 Department of Horticulture, Bangladesh Agricultural University, Mymensingh 2202, Bangladesh.

${ }^{3}$ Soil Science Division, Bangladesh Rice Research Institute, Gazipur 1701., Bangladesh.
} 
preparation of cake and "Morobba". Sometimes mature fruits are also used as vegetable. The ash gourd fruit juice is used in Ayurvedic medicine for treating a range of ailments including insanity and epilepsy (Ramesh et al., 1989). A special type of popular ingredient of vegetable dish commonly known as "Bori", is also made by flesh of ripened ash gourd mixed with black gram powder. Ash gourd is one of the most common summer vegetable grown in Bangladesh. The country has been earning a good amount of foreign currency by exporting green ash gourd to the United Kingdom, Pakistan and Middle East (Alamgir, 1981). It comes in the market when there is a crisis of vegetables. Among the vegetables under cucurbitaceae family and other creepers usually ash gourd gives the higher economic return for marginal farmers (Chowdhury, 1993). In Bangladesh, vegetable production is not uniform throughout the year and most of the vegetables are produced in winter. So there is a scarce of vegetable in summer season. The ash gourd production can meet up this crisis (Rahman, 1994). In Bangladesh, total production of ash gourd is about 134,000 metric tons in the year of 2009-10 (BBS, 2010). There are several causes of such low yield. The most important one is the lack of high yielding varieties. Although, ash gourd is an important vegetable crop for the summer, there is no recommended variety in Bangladesh and very little effort has been made in Bangladesh regarding the improvement of ash gourd in this country. In Bangladesh, there are many genotypes of ash gourd having different characters. A study of yield and its components and their relative contribution to the yield is of great importance in planning an effective breeding programme. To meet the diverse goals of plant breeding such as producing cultivars with increased yield, wider adaptation, desirable quality and pest and disease resistance we need to evaluate the existing genotypes at phenotypic and genotypic level. Considering the above facts, the present study was undertaken to assess the performance and genotypic diversity of ash gourd genotypes for yield and yield contributing characters.

\section{MATERIALS AND METHODS}

The study was conducted under the Project of "Collection, Evaluation, Conservation and Utilization of Landraces and Wild relatives of some Important Vegetables and Fruits of Bangladesh (CVFB)" at the Horticulture Farm, Bangladesh Agricultural University, Mymensingh. In this experiment 46 ash gourd genotypes were used as experimental materials which were collected from different places of Bangladesh. The experiment was laid out in Randomized Complete Block Design (RCBD) with three replications. Each replication consists with three plants from each genotype. The distance between pits was $1.5 \mathrm{~m}$ and row to row was $2.0 \mathrm{~m}$. The experimental bed was $4.5 \mathrm{~m} \times 1.5 \mathrm{~m}$ in size and was prepared at a height of $10 \mathrm{~cm}$ from the ground level in the experimental plot by spade. After bed preparation, the pits were prepared with the help of spade. Recommended dose of manure and fertilizers were applied in the experimental plot for ash gourd cultivation (Anonymous 1994). The seeds of different genotypes were dibbled in the pit of raised beds. The seedlings were observed carefully. Different types of intercultural operations were done during the growing period of crop. Trellis and staking were provided and support was given to the plants by bamboo sticks to facilitate climbing up the plant easily and to protect the fruits from soil pest and pathogens. The trellis also facilitated easy harvesting of the fruits. Pests were controlled as and when needed. Green fruits were harvested in every month when they attained in edible stage. Vine length at harvest, number of flowers (male and female) per plant, sex ratio (male: female), fruit length (at green stage), fruit diameter (at green stage), fruit weight, flesh thickness (at green stage), fruits per plant, yield per plant were recorded during the experimental period. 
The data in respect of yield and yield contributing characters were statistically analyzed using MSTAT software. The means for all treatments were calculated and analyses of variances for all characters were performed by F -test (Gomez and Gomez 1984). Data recorded on eight characters viz., vine length (at harvest), sex ratio, fruit length, fruit diameter, flesh thickness, average weight fruit ${ }^{-1}$, number of fruit plant $^{-1}$ and yield plant $^{-1}$ were subjected to multivariate analysis according to GENSTAT 513 (Mahalanobis, 1936 and Digby et al., 1989).

\section{RESULTS AND DISCUSSION}

Mean performance on yield and yield contributing characters of 46 ash gourd genotypes are shown in Table 1 . The vine length of plant at harvest varied significantly among the genotypes. The tallest vine length at harvest was found in $\mathrm{BH} 7(10.57 \mathrm{~m})$ which was statistically similar with BH14, BH15, and BH54 (10.09 m, $10.14 \mathrm{~m}$ and $10.14 \mathrm{~m}$, respectively) while the shortest vine length at harvest was recorded in $\mathrm{BH} 24$ $(5.12 \mathrm{~m})$ which was statistically different with other genotype (Table 1$)$. This character is known as an important for the variability study as fruit bearing depends on vine length. Masud (1995) reported that vine length at harvest were 2.76 to $5.76 \mathrm{~m}$ in pumpkin.

Sex ratio of male and female flower varied significantly among the genotypes. The height sex ratio (8.45) was recorded in the genotype BH18 which was statistically similar with the genotype BH64 (8.16). The lowest sex ratio (3.44) was found in the genotype BH14 which was statistically different from other genotypes (Table 1). The lowest sex ratio indicated the highest number of female flowers and the lowest number of male flowers. So this character is important for varietal selection. Sheshadri (1986) also reported that the ratio of male and female flowers ranged from 25: 1 and 15: 1 .

In respect of fruit length, significant variation was observed among the genotypes at edible stage. The maximum fruit length $(29.64 \mathrm{~cm})$ was observed in the accession BH56 which was statistically similar with the accession BH2, BHI4, BH20, $\mathrm{BH} 21, \mathrm{BH} 23, \mathrm{BH} 26, \mathrm{BH} 28, \mathrm{BH} 36, \mathrm{BH} 59$ and $\mathrm{BH} 63$. While the minimum fruit length $(14.83 \mathrm{~cm}$ ) was found in the accession BB 17 (Table 1). As regards fruit diameter, it ranged from 26.00 to $42.33 \mathrm{~cm}$ (at edible stage) which significantly varied among the studied accessions of ash gourd. The highest diameter of fruit $(42.33 \mathrm{~cm}$ was obtained from the genotype $\mathrm{BH} 45$ and the smallest diameter of fruit $(26.00 \mathrm{~cm})$ was recorded from the genotype BH17 (Table 1). Moreover, Masud (1995) reported that fruit diameter ranged from 17.44 to $29.00 \mathrm{~cm}$ in pumpkin germplasm. The flesh thickness of fruit varied significantly among the genotypes at edible stages. The maximum flesh thickness $(2.40 \mathrm{~cm})$ was observed in the genotype BH44 which was statistically similar with the genotype BH45 $(2.36 \mathrm{~cm})$ and the minimum flesh thickness $(1.30 \mathrm{~cm})$ was recorded from the genotype BH19 which was statistically similar with the genotype BH17 and BH38 $1.50 \mathrm{~cm}$, respectively (Table 1).

Significant variations in respect of the number of fruits plant-1 among the genotypes were obtained which ranged from 1.83 to 16.16. The plants of $\mathrm{BH} 46$ and BH53 produced the minimum number of fruits (1.83) where as genotype $\mathrm{BH} 21$ bore the maximum number of fruits (16.16) which was statistically similar with the genotype BH12 (15.00) (Table 1). This character is very important for the varietal selection because yield depends upon the number of fruits plant ${ }^{-1}$. Average weight green ${ }^{-1}$ fruit varied significantly among the genotypes which ranged from 0.67 to $1.86 \mathrm{~kg}$. The fruit of the genotype BHI6 was the heaviest $(1.86 \mathrm{~kg})$ which was statistically similar with the genotype $\mathrm{BH} 12$ and $\mathrm{BH} 21$ and the genotype $\mathrm{BH} 17$ had the lowest average weight $(0.67$ $\mathrm{kg}$ ) which was not statistically similar with other genotypes. 
Table 1. Mean performance on yield and yield contributing characters of 46 ash gourd genotypes

\begin{tabular}{|c|c|c|c|c|c|c|c|c|}
\hline Treatment & $\begin{array}{l}\text { Vine } \\
\text { length at } \\
\text { harvest } \\
\text { (m) }\end{array}$ & $\begin{array}{c}\text { Sex } \\
\text { ratio }\end{array}$ & $\begin{array}{c}\text { Fruit } \\
\text { length } \\
(\mathrm{cm})\end{array}$ & $\begin{array}{l}\text { Fruit } \\
\text { diameter } \\
(\mathrm{cm})\end{array}$ & $\begin{array}{l}\text { Flesh } \\
\text { thickness } \\
\quad(\mathrm{cm})\end{array}$ & $\begin{array}{l}\text { No. of } \\
\text { fruits } \\
\text { plant }^{-1}\end{array}$ & $\begin{array}{c}\text { Avera } \\
\text { ge wt } \\
\text { fruit }^{-1} \\
(\mathrm{~kg})\end{array}$ & $\begin{array}{c}\text { Yield } \\
\text { plant }^{-1} \\
(\mathrm{~kg})\end{array}$ \\
\hline BH1 & 9.55 & 5.80 & 21.05 & 35.10 & 1.80 & 8.50 & 1.02 & 8.60 \\
\hline $\mathrm{BH} 2$ & 7.79 & 4.70 & 27.64 & 40.66 & 1.98 & 7.00 & 1.36 & 9.50 \\
\hline BH5 & 8.26 & 4.89 & 24.00 & 34.00 & 1.70 & 12.10 & 1.14 & 13.68 \\
\hline BH6 & 9.08 & 6.52 & 25.50 & 39.33 & 1.93 & 6.30 & 1.36 & 8.64 \\
\hline BH7 & 10.15 & 5.76 & 23.00 & 34.66 & 1.76 & 9.60 & 1.39 & 13.41 \\
\hline BH8 & 9.01 & 6.17 & 24.40 & 34.46 & 2.00 & 7.00 & 1.37 & 9.68 \\
\hline BH9 & 8.26 & 7.21 & 23.33 & 33.80 & 1.80 & 7.50 & 1.18 & 8.77 \\
\hline BH10 & 7.04 & 6.16 & 22.33 & 33.16 & 2.23 & 3.20 & 1.20 & 3.82 \\
\hline BH11 & 7.55 & 6.15 & 20.50 & 39.66 & 2.03 & 4.80 & 1.40 & 6.82 \\
\hline BH12 & 9.87 & 4.67 & 25.33 & 35.66 & 1.88 & 15.10 & 1.66 & 25.45 \\
\hline BH14 & 10.09 & 3.44 & 28.33 & 32.83 & 1.76 & 4.50 & 1.41 & 6.36 \\
\hline BH15 & 10.14 & 4.46 & 25.40 & 32.46 & 2.16 & 4.22 & 1.46 & 6.32 \\
\hline BH16 & 9.73 & 6.52 & 25.00 & 38.33 & 1.93 & 8.85 & 1.86 & 16.77 \\
\hline BH17 & 6.76 & 6.68 & 14.83 & 26.00 & 1.50 & 8.00 & 0.67 & 5.41 \\
\hline BH18 & 7.04 & 8.45 & 24.23 & 36.46 & 1.53 & 6.70 & 1.03 & 6.77 \\
\hline BH19 & 7.28 & 6.44 & 24.83 & 38.66 & 1.30 & 5.50 & 1.52 & 8.63 \\
\hline BH20 & 7.37 & 5.38 & 27.33 & 38.66 & 1.93 & 4.20 & 1.70 & 6.82 \\
\hline BH21 & 9.27 & 3.80 & 27.20 & 37.56 & 1.56 & 16.16 & 1.73 & 27.83 \\
\hline BH23 & 6.09 & 5.34 & 28.00 & 37.00 & 2.06 & 5.80 & 1.75 & 10.40 \\
\hline BH24 & 5.12 & 7.18 & 23.83 & 35.66 & 1.86 & 8.74 & 1.35 & 11.82 \\
\hline BH25 & 7.42 & 7.31 & 19.16 & 32.33 & 1.60 & 10.91 & 1.38 & 15.00 \\
\hline BH26 & 7.18 & 4.92 & 27.33 & 31.00 & 1.60 & 8.20 & 1.24 & 10.45 \\
\hline BH27 & 7.24 & 4.89 & 21.66 & 32.33 & 1.93 & 5.50 & 1.78 & 9.91 \\
\hline BH28 & 7.87 & 6.03 & 26.83 & 29.83 & 1.53 & 3.50 & 1.20 & 4.32 \\
\hline BH34 & 7.88 & 6.29 & 24.50 & 33.33 & 1.63 & 8.50 & 1.48 & 12.22 \\
\hline BH36 & 6.42 & 4.32 & 28.00 & 33.66 & 1.86 & 3.40 & 1.00 & 3.41 \\
\hline BH38 & 7.04 & 5.66 & 21.83 & 39.50 & 1.50 & 5.80 & 0.93 & 5.54 \\
\hline ВН39 & 7.08 & 5.96 & 22.50 & 29.33 & 1.56 & 4.50 & 1.52 & 7.27 \\
\hline BH40 & 9.02 & 7.15 & 25.26 & 32.13 & 1.80 & 12.05 & 1.46 & 17.41 \\
\hline BH42 & 5.38 & 5.35 & 25.00 & 39.33 & 1.83 & 11.18 & 1.19 & 13.63 \\
\hline BH43 & 7.98 & 5.62 & 24.70 & 35.33 & 1.56 & 8.30 & 1.18 & 10.00 \\
\hline BH44 & 8.07 & 6.17 & 25.33 & 29.00 & 2.40 & 12.32 & 1.36 & 17.18 \\
\hline BH45 & 7.52 & 6.50 & 22.33 & 42.33 & 2.36 & 3.30 & 1.32 & 4.50 \\
\hline BH46 & 6.63 & 7.05 & 25.00 & 35.66 & 1.80 & 1.83 & 1.00 & 1.90 \\
\hline BH47 & 8.84 & 6.33 & 22.33 & 33.00 & 1.53 & 5.83 & 1.34 & 7.95 \\
\hline BH48 & 7.34 & 6.03 & 25.64 & 38.00 & 1.91 & 9.94 & 1.70 & 17.10 \\
\hline BH50 & 9.76 & 6.52 & 24.33 & 32.83 & 1.80 & 13.07 & 1.30 & 17.27 \\
\hline BH53 & 8.92 & 6.91 & 25.83 & 29.00 & 1.76 & 1.83 & 1.05 & 1.97 \\
\hline BH54 & 10.14 & 7.14 & 24.00 & 34.33 & 1.53 & 9.10 & 1.71 & 15.81 \\
\hline BH56 & 9.89 & 6.96 & 29.64 & 33.33 & 1.90 & 4.50 & 1.51 & 7.04 \\
\hline BH57 & 8.47 & 5.95 & 26.00 & 39.00 & 1.90 & 7.56 & 1.49 & 11.77 \\
\hline BH59 & 6.54 & 7.65 & 26.64 & 39.00 & 1.86 & 3.20 & 1.67 & 5.36 \\
\hline BH61 & 9.04 & 5.25 & 22.33 & 40.16 & 1.86 & 11.10 & 1.36 & 15.45 \\
\hline BH63 & 6.58 & 5.80 & 26.33 & 33.33 & 1.63 & 4.16 & 0.98 & 4.10 \\
\hline BH64 & 7.39 & 8.16 & 25.83 & 33.83 & 1.83 & 3.68 & 1.14 & 4.10 \\
\hline BH65 & 9.49 & 7.51 & 20.00 & 31.33 & 1.70 & 3.10 & 0.86 & 2.91 \\
\hline $\operatorname{LSD}(0.05)$ & 0.10 & 0.29 & 3.41 & 5.96 & 0.23 & 1.24 & 0.20 & 1.82 \\
\hline Range & $\begin{array}{l}5.12- \\
10.15\end{array}$ & $\begin{array}{c}3.44- \\
8.45\end{array}$ & $\begin{array}{l}14.83- \\
29.66\end{array}$ & $\begin{array}{c}26.66- \\
42.33\end{array}$ & $1.30-2.40$ & $\begin{array}{c}1.83- \\
16.16\end{array}$ & $\begin{array}{c}0.67- \\
1.86\end{array}$ & $\begin{array}{l}1.90- \\
27.83\end{array}$ \\
\hline Mean value & 8.05 & 6.07 & 24.45 & 34.92 & 1.80 & 4.02 & 1.34 & 9.85 \\
\hline
\end{tabular}

This character is important for variability test because yield of every plant depends upon the average weight fruit ${ }^{-1}$. However, Rahman (1996) reported that average weight fruit ${ }^{-1}$ 
ranged from 0.94 to $1.72 \mathrm{~kg}$. The ash gourd genotypes varied significantly for fruit yield per plant which ranged from $1.90 \mathrm{~kg}$ to $27.83 \mathrm{~kg}$ with the average value of $9.85 \mathrm{~kg}$. The highest yield of fruit plant ${ }^{-1}(27.83 \mathrm{~kg})$ was recorded in the genotype $\mathrm{BH} 21$ which was not statistically similar with other genotypes where as the lowest yield of fruit plant ${ }^{-1}$ $(1.90 \mathrm{~kg})$ was found from genotype $\mathrm{BH} 46$, which was statistically different from other genotypes. This character is very important for varietal improvement. Ching (1998) also reported that yield of ash gourd was $27.3 \mathrm{~kg} \mathrm{plant}^{-1}$.

\section{Clustering of genotypes}

In cluster analysis, the genotypes were grouped into eight different clusters (Table 2). Clusters I, II, III, IV, V, VI, VII, and VIII composed one, two, seventeen, eleven, nine, three, four, and three genotypes, respectively. The distribution pattern indicated that the maximum number of genotypes (17) were included in cluster III followed by group V, IV and VII with 9, 7 and 4 genotypes, respectively. The cluster I and II were composed of solitary genotype $\mathrm{BH} 17$ and $\mathrm{BH} 12$, respectively. But the genotypes $\mathrm{BH} 2, \mathrm{BH} 5, \mathrm{BH} 6, \mathrm{BH} 7, \mathrm{BH} 8, \mathrm{BHI} 6, \mathrm{BHI} 9, \mathrm{BH} 23, \mathrm{BH} 24, \mathrm{BH} 25, \mathrm{BH} 34$, $\mathrm{BH} 42, \mathrm{BH} 43, \mathrm{BH} 48, \mathrm{BH} 54, \mathrm{BH} 57$ and $\mathrm{BH} 61$ were included in cluster III. The genotypes BHI, BH9, BHI8, BH26, BH27, BH39 and $\mathrm{BH} 47$ were in cluster IV; BHI4, BHI5, BH20, BH28, BH36, BH46, BH56, BH63 and BH64 in cluster V; BH40, BH44 and BH50 in cluster VI; BH11, BH38, BH45 and BH59 in cluster VII and BHI0, BH53 and BH65 in cluster VIII.

Table 2. Distribution of 46 ash gourd genotypes in 8 clusters including source of collection

\begin{tabular}{|c|c|c|}
\hline $\begin{array}{l}\text { Cluster } \\
\text { No. }\end{array}$ & $\begin{array}{l}\text { No. of genotypes } \\
\text { in cluster }\end{array}$ & $\begin{array}{l}\text { Name of genotypes in each cluster and source of } \\
\text { collection }\end{array}$ \\
\hline I & 1 & BH17 (Mymensingh) \\
\hline II & 2 & BH17 (Mymensingh), BH21 (Tangail) \\
\hline III & 17 & $\begin{array}{l}\text { BH2 (Jamalpur), BH5 (Jamalpur), BH6 (Mymensingh), } \\
\text { BH7 (Mymensingh), BH8 (Mymensingh), BH16 (Pabna), } \\
\text { BH19 (Panchaghar), BH23 (Pabna), BH24 (Pabna), } \\
\text { BH25 (Pabna), BH34 (Mymensingh), BH42 (Rajshahi), } \\
\text { BH43 (Rajshahi), BH48 (Gaibandha), BH54 (Comilla), } \\
\text { BH57 (Chittagong), BH61 (Chittagong) }\end{array}$ \\
\hline IV & 7 & $\begin{array}{l}\text { BH1 (Mymensingh), BH9 (Mymensingh), } \\
\text { (Mymensingh), BH26 (Pabna), BH27 (Pabna), } \\
\text { (Mymensingh), BH47 (Gaibangha) }\end{array}$ \\
\hline $\mathrm{V}$ & 9 & $\begin{array}{l}\text { BH14 (Mymensingh), BH15 (Pabna), BH20 (Tangail), } \\
\text { BH28 (Pabna), BH36 (Mymensingh), BH46 } \\
\text { (Gaibangha), BH56 (Chittaging), BH63 (Natore), BH64 } \\
\text { (Dinajpur) }\end{array}$ \\
\hline VI & 3 & BH40 (Rajshahi), BH44 (Rajshahi), BH50 (Comilla) \\
\hline VII & 4 & $\begin{array}{l}\text { BH11 (Mymensingh), BH38 (Mymensingh), BH45 } \\
\text { (Gaibandha), BH59 (Chittagong) }\end{array}$ \\
\hline VIII & 3 & $\begin{array}{l}\text { BH10 (Mymensingh), BH53 (Comilla), } \\
\text { (Patuakhali) }\end{array}$ \\
\hline
\end{tabular}

Raseed et al. (2002) reported that seven cluster groups in pumpkin. The cluster grouping of the genotypes under this study revealed that the accessions collected from the same district were grouped into different clusters. As for example genotypes of Mymensingh 
district were distributed in seven clusters out of eight. Similar opinion was also suggested by Masud et al. (2001).

\section{Cluster means}

Intra cluster means for eight characters are shown in Table 3. The cluster I comprising the single genotype BHI7 produced second highest cluster mean for sex ratio and the lowest mean value for fruit length, fruit diameter, flesh thickness, average weight fruit $^{1}$ and vine length. The cluster II recorded the highest mean for average weight fruit ${ }^{1}$, vine length, number of fruits plant ${ }^{1}$ and yield plant ${ }^{1}$ and the lowest cluster mean for sex ratio. The genotypes $\mathrm{BH} 2, \mathrm{BH} 5, \mathrm{BH} 6, \mathrm{BH} 7, \mathrm{BR} 8, \mathrm{BH} 16, \mathrm{BH} 19, \mathrm{BH} 23, \mathrm{BH} 24, \mathrm{BH} 25$, BR34, BH42, BH43, BH48, BH54, BH57 and BH61 in cluster III produced second highest cluster mean for fruit diameter and average weight fruit ${ }^{-1}$.

Table 3. Cluster means for eight characters of 46 ash gourd genotypes

\begin{tabular}{|c|c|c|c|c|c|c|c|c|}
\hline \multirow[t]{2}{*}{ Characters } & \multicolumn{8}{|c|}{ Cluster } \\
\hline & $\mathrm{I}$ & II & III & IV & $\mathrm{V}$ & VI & VII & VIII \\
\hline Vine length (m) & 6.77 & 9.58 & 8.01 & 7.89 & 8.05 & 8.95 & 7.16 & 8.49 \\
\hline Fruit length $(\mathrm{cm})$ & 14.83 & 26.27 & 24.56 & 23.27 & 26.97 & 24.98 & 22.83 & 22.72 \\
\hline Fruit diameter $(\mathrm{cm})$ & 26.00 & 36.62 & 36.74 & 33.00 & 33.74 & 31.32 & 40.13 & 31.17 \\
\hline Flesh thickness $(\mathrm{cm})$ & 1.50 & 1.72 & 1.79 & 1.68 & 1.83 & 2.00 & 1.94 & 1.83 \\
\hline Sex ratio (male: female) & 6.68 & 4.24 & 6.03 & 6.23 & 5.74 & 6.62 & 6.49 & 6.86 \\
\hline No. of fruit plant ${ }^{-1}$ & 8.00 & 15.58 & 8.64 & 6.67 & 3.78 & 12.44 & 4.29 & 2.72 \\
\hline Average weight fruit ${ }^{-1}(\mathrm{~kg})$ & 0.67 & 1.69 & 1.45 & 1.30 & 1.27 & 1.37 & 1.33 & 1.05 \\
\hline Yield plant $^{-1}(\mathrm{~kg})$ & 5.33 & 26.43 & 12.40 & 8.40 & 4.88 & 17.08 & 5.47 & 1.48 \\
\hline
\end{tabular}

The seven genotypes $\mathrm{BH}$, BH9, $\mathrm{BH} 18, \mathrm{BH} 26, \mathrm{BH} 27, \mathrm{BH} 39$ and $\mathrm{BH} 47$ in cluster IV produced moderate cluster mean for almost all the characters. The cluster $\mathrm{V}$ possessing the nine genotypes $\mathrm{BH} 14, \mathrm{BH} 15, \mathrm{BH} 20, \mathrm{BH} 28, \mathrm{BH} 36, \mathrm{BH} 46, \mathrm{BH} 56, \mathrm{BH} 63$ and BH64 produced the highest cluster mean for fruit length. The cluster VI had the highest cluster mean for flesh thickness and second highest for vine length, number of fruits plant ${ }^{-1}$ and yield plant ${ }^{-1}$. The highest clusters mean for fruit diameter and second highest for flesh thickness were recorded in cluster VII. The cluster VIII containing three genotypes $\mathrm{BH} 10, \mathrm{BH} 53$ and $\mathrm{BH} 65$ produced the highest cluster mean for sex ratio and lowest cluster mean for number of fruits plant ${ }^{-1}$ and yield plant ${ }^{-1}$. The result of the present study revealed that a wide range of variability existed among the collected ash gourd genotypes. The 46 genotypes were grouped into eight different clusters, which proved a wide range of variation exist among the tested genotypes. However, there was no relationship found between genetic divergence and geographic distribution of the genotypes. These variabilities can be used for future breeding programme of ash gourd in our country.

\section{REFERENCES}

Alamgir, M. 1981. Export potential of non-traditional agricultural products of Bangladesh. Bangladesh Quart., 1(3): 12-13.

Anonynmous. 1994. Vegetable Research Programme for the year 1994-95. Olericulture Division, HRC, BARI, Joydebpur. p. 17.

BBS. 2010. Statistical Year Book of Bangladesh. Bangladesh Bureau of Statistics. Ministry of Planning. Government of People's Republic of Bangladesh, Dhaka. p. 134. 
Ching, A. 1998. Evaluation of two Benincasa hispida genotypes for fruit yield, vine growth, size and shape characteristics. Report on CucurbitsGenetics-Cooperative., 21: 67-68.

Chowdhury, M. K. 1993. Homestead vegetable production technology for different agro climatic zones of Bangladesh. In: Intensive vegetable growing and its utilization. Compiled by M. L. Chadha and others (ed). A compilation of lecture materials of a training course held in BARI, Joydebpur. Gazipur, Bangladesh. p. 27.

De Candolle, A. 1986. Origin of Cultivated Plants, Hafner Publ. Co. USA. p. 235.

Digby, P., N. Galway and P. Lane. 1989. GENSTAT 5 : A Second Course. Oxford Science Publications, Oxford. pp. 103-108.

Gomez, K. A. and A. A. Gomez. 1984. Statistical Procedure for Agricultural Research. John Wiley and Sons. Inc. New York. pp. 67-215.

Mahalanobis, P. C. 1936. On the generalized distance in statistics. Proc. Natl. Inst. Sci., India. 2: 49-55

Masud, M. A. T. 1995. Variability association and genetic diversity in pumpkin (Curcurbita moschata Duch ex poir) M.S. Thesis, Department of Horticulture, BAD, Mymensingh. pp. 38-50.

Masud, M. A. T., A. K. M. A. Habib, S. U. Ahmad and S. M. M. Hossain, 2001. Genetic diversity in sponge gourd (Luffa cylindrica). Bangladesh J. Plant Breed. Genet., 14(2): 37-41.

Purseglove, J. W. 1987. Tropical Crops, Dicotyledons. Longman Science and Technology, England. p. 101.

Rahman, L. 1994. Promotion of private vegetable industries in Bangladesh. Problems and prospects. In: Vegetables research and development in Bangladesh. Proceedings of a symposium on recent advances in vegetable development of Bangladesh, BARI, Joydebpur, Gazipur, Bangladesh. p.136.

Rahman, M. M. 1996. Floral biology of ash gourd. MS. Thesis, Department of Genetics and Plant Breeding, Institute of Postgraduate studies in agriculture (IPSA), Salna, Gazipur. p.71.

Ramesh, M., V. Gayathri, A. V. N. A. Rao, M. C. Prabhakar and C. S. Rao, 1989. Pharmacological actions of fruit juice of Benincasa hispida. Fitoterapia. 60(3): 241-247.

Raseed, M. M., S. A. Nabi, M. G. Rasul and M. A. K. Mian. 2002. Genetic divergence in pumpkin (Cucurbita moschata). Bangladesh J. Plant Breed. Genet., 15(1): 39-41.

Sheshadri, V. S. 1986. Cucurbits. In: T. K. Bose and M. G. Som (Eds). Vegetable Crops in India, Naya Prokash, Calcutta. 6, India. p. 280.

Tindall, H. D. 1986. Vegetables in the Tropics. Macmillan Education Ltd. Basingstake, Hampshire, UK. p. 147.

Yawalkar, K. S. 1985. Vegetable Crops of India. ( $3^{\text {rd }}$ Edition). Horticultural Publishing House, Nagpur-440010. India. p. 124. 